\title{
FLUXUS ANIMASI DAN KOMUNIKASI DI ERA MEDIA BARU DIGITAL
}

\author{
Zuhdan Aziz \\ Universitas Muhammadiyah Yogyakarta \\ zuhdanaziz.umy@gmail.com \\ *corresponding author
}

Keywords:

fluxus, animation and

communication, new digital media

\begin{abstract}
Animation has only been seen as a luxurious, expensive and sophisticated media in the production process so that the development is limited to big screen films and television shows and audiovisual art. However, along with the development of increasingly sophisticated digital information and computer technology increasingly ushered in animation as an important object capable of establishing itself as an amazing medium. Sophisticated computer animation, both hardware and software, is able to translate imagination and creativity. Animation is becoming more affordable, cheaper and more attractive so that it can be present and used by the wider community in various fields. There is a lot of hybridization between animation and many fields such as architecture, art, entertainment, learning media and even communication media. Even this research aims to find out the forms of fluxus variation between animation and communication. With a qualitative descriptive method, the development of usage from the results of animated hybridization in the field of communication in the era of digital new media can be explored.

The results of the study show that animation has become an attractive medium, which is able to find its identity in the universe of modern digital electronic media. Animation can be used as a function of communication, as a medium of information, entertainment, persuasion and education in various forms. Animations can take the form of films, simulations, youtube content, video clips, learning media, presentation media, multi media, complementary features of smartphones / gadgets or social media, online games, audio-visual artwork and so on. The conclusion is that the existence of animation as a container or media of communication has attracted various fields to interact and process with it so that there are various variations of fluxus (mixing or merging) of works and functions and interests of various fields including communication. The advice offered is to make animation as a large container that can accommodate many things in it. As a container or media, animation is neutral, depending on who (the communicator) wants to convey the message, interpret, utilize and direct it according to the stated communication objectives so that it can be very effective.
\end{abstract}

\begin{abstract}
ABSTRAK
Animasi selama ini hanya dipandang sebagai media yang mewah, mahal dan sophisticated dalam proses produksinya sehingga perkembangan terbatas pada film layar lebar maupun tayangan televisi serta karya seni audiovisual. Namun, seiring perkembangan teknologi informasi digital dan komputer yang semakin canggih semakin mengantarkan animasi sebagai obyek penting yang mampu mengukuhkan dirinya menjadi media yang menakjubkan. Kecanggihan animasi komputer, baik secara hardware maupun software, mampu menerjemahkan imajinasi dan kreatifitas. Animasi menjadi semakin mudah, murah dan menarik sehingga mampu hadir dan digunakan oleh masyarakat luas dalam berbagai
\end{abstract}


bidang. Banyak terjadi hibridisasi antara animasi dengan banyak bidang seperti arsitektur, seni, entertainment, media pembelajaran bahkan media komunikasi. Penelitian inipun bertujuan untuk mengetahui bentuk-bentuk vareasi fluxus antara animasi dengan komunikasi. Dengan metode deskriptif kualitatif, dapat digali perkembangan penggunaan dari hasil hibridisasi animasi dalam bidang komunikasi di era media baru digital.

Hasil penelitian menunjukkan bahwa animasi telah menjelma menjadi media yang menarik, yang mampu menemukan jatidirinya dalam jagad media elektronik digital modern. Animasi dapat digunakan sebagaimana fungsi komunikasi, sebagai media informasi, hiburan, persuasi dan pendidikan dalam berbagai bentuknya. Animasi bisa berbentuk film, simulasi, content youtube, video clip, media pembelajaran, media presentasi, multi media, fitur pelengkap smartphone/gadget atau media social, games online, karya seni audio visual dan lain sebagainya. Kesimpulannya bahwa eksistensi animasi sebagai wadah atau media komunikasi telah menarik berbagai bidang untuk berinteraksi dan berproses dengannya sehingga terjadi berbagai vareasi fluksus (percampuran atau penggabungan) karya dan fungsi serta kepentingan dari berbagai bidang termasuk komunikasi. Saran yang ditawarkan adalah menjadikan animasi sebagai wadah besar yang mampu menampung banyak hal di dalamnya. Sebagai wadah atau media, animasi bersifat netral, tergantung siapa (komunikator) yang mau menyampaikan pesan, memaknai, memanfaatkan

Kata Kunci:

fluxus, animasi dan komunikasi, media baru digital dan mengarahkannya sesuai tujuan komunikasi yang ditetapkan sehingga bisa sangat efektif.

Copyright (C) 2019 Channel Jurnal Komunikasi. All right reserved.

\section{PENDAHULUAN}

Hampir setiap saat, manusia saling berkomunikasi dan berinteraksi antara satu dengan yang lain, baik secara lisan, tulisan, suara atau visual yang disampaikan. Berkomunikasi bukan hanya dengan kata saja, tetapi bisa juga dengan gestur berupa gerakan-gerakan tubuh dan ekspresi wajah yang ditimbulkan oleh rasa dari dalam diri manusia, seperti takut sedih, atau senang. Selain gestur, komunikasi bisa juga dilakukan dengan menggunakan simbol-simbol tulisan maupun gambar. Manusia menyadari bahwa gambar bisa dipakai sebagai alternatif sarana komunikasi, sehingga timbul keinginan untuk menghidupkan gambar tersebut menjadi cermin ekspresi kebudayaan. Terbukti dengan ditemukannya berbagai artefak piktografi dan ideografi berupa lukisan-lukisan atau gambar dalam gua-gua pra sejarah.

Setelah media digital makin berkembang, media televisi dan internet memberikan wadah yang kuat bagi tumbuh berkembangnya gambar visual, khususnya dalam dunia animasi. Dengan adanya teknik-teknik software animasi, gambargambar diam dapat digerakkan, seolah-olah menjadi hidup dan bernyawa seperti halnya manusia hidup. Keinginan manusia untuk membuat gambar atau santiran (image) yang hidup dan bergerak sebagai perantara dari pengungkapan (expression) mereka, merupakan perwujudan dari bentuk dasar animasi yang hidup dan berkembang. Animasi memberikan daya tarik visual dengan menayangkan bukan hanya soal cerita dan karakter, tetapi juga menyajikan gerakan-gerakan serta suara-suara yang hidup, untuk dapat dinikmati penontonnya. Animasi adalah suatu teknik untuk mewujudkan keinginan, khayalan dan imajinasi manusia menjadi sesuatu yang kasatmata, dapat dilihat dan dirasakan. Dalam membuat animasi yang terpenting adalah pergerakan. Kepekaan untuk mengamati pergerakan benda-benda, lebih bisa mendekatkan pada realita menjadikan animasi yang semakin hidup, apalagi didukung kreativitas dan imajinasi (Suciadi, 2001:1).

Banyak definisi animasi dengan membaginya menjadi 2 dimensi, 3 dimensi, atau anime, sehingga pengenalan animasi ini hanya sebatas pada hal demikian. Padahal animasi berbicara lebih dari sekedar definisi-definisi seperti itu. Menurut Animator Jepang, Nakami dikatakan bahwa: walaupun teknik animasi 3 D lebih baru dan dapat menampilkan objek dari 3 sudut pandang secara real, namun bukan berarti animasi 2D mempunyai status lebih rendah dibandingkan animasi 3 D. Animasi 3D memiliki kelebihan pada kemampuannya memperlihatkan obyek secara real, sedangkan animasi 2D mempunyai kelebihan pada seni gambarnya. Antara teknik animasi 3 D dan 2 D mempunyai kelebihannya masingmasing dan statusnya sejajar (dalam Soewignya, 2004:11).

Dalam perkembangannya, di era peralatan dan bahan masih serba analog dan kimiawi, Animasi kartun (2D) sudah bisa berkembang dan banyak digemari, namun sebatas sebagai tontonan anak kecil. Fenomena animasi juga masih terbatas pada tontonan film layar lebar di bioskop atau tayangan televisi. Animasi saat itu juga terbatas pada bentuk karya- karya seni audio visual pada ruang-ruang pertunjukan yang terbatas, seperti di kampus atau galleri museum seni. 
Pembuatan Animasi masih dianggap terlalu sophisticated dan mahal dengan teknologi computer yang teramat sulit dan rumit. Animasi menjadi media komunikasi yang serba terbatas ruang lingkupnya.

Berbeda dengan yang terjadi di era digital, animasi tumbuh berkembang menjadi media baru yang menarik. Perangkat hardware maupun software computer animasi semakin berkembang dan canggih sehingga mengantarkan proses produksi animasi semakin berkembang, mudah dan murah. Termasuk cara distribusi karya animasi yang semakin bervareasi dan massif. Kondisi tersebut, memungkinkan diproduksinya karya-karya animasi dalam berbagai lini kehidupan penting manusia. Animasi menjelma menjadi media pembelajaran, media Pendidikan, media Dongeng, media komunikasi, media persuasi, media informasi grafis bergerak, meia Tutorial, media simulasi, media hiburan (entertainment), media games, media film, media Seni dan berbagai media yang lain.

Kedahsyatan dan keunikan animasi telah mengantarkannya sebagai jembatan untuk menuangkan ide-ide fiksi fantasi maupun realitas dalam bentuk karya, termasuk karya artistik dengan eksplorasi estetika seni. Disisi lain, daya tarik animasi yang bisa menyedot perhatian banyak orang, telah mampu untuk dijual menjadi komoditas industri massa yang mampu mendatangkan banyak keuntungan dan menghidupkan roda bisnis dan perekonomian. Singkatnya, animasi telah menjadi magnet yang kuat untuk menuangkan segala ide, gagasan dan ekspresi serta mampu menjadi industri kreatif yang menarik dan menjanjikan dalam kehidupan masyarakat modern.

Kreativitas dalam dunia animasi, semakin lama semakin bervareasi dan menggairahkan. Ibarat sirkus, animator senantiasa berakrobat untuk selalu menarik perhatian penontonnya. Resep untuk menarik perhatian itu semakin lama terus berkembang, dengan berbagai inovasi atau menggabungkan banyak hal (fluxus) menjadi suatu terobosan yang mampu menyedot perhatian orang. Efek takjub kemudian dimasukkan, dan pada akhirnya penonton merasa terkesima dan terhanyut didalam narasinya lalu sangat intens perhatiannya.

Dalam perkembangannya, animasi mampu menjembatani antara idealisme dan bisnis. Sungguh mencengangkan, dibuatnya film-film animasi untuk konsumsi bioskop, ternyata mampu menjadi box office (sangat laku di pasaran atau menjadi yang paling digemari) bahkan sequelnya dibuat sebagai kelanjutan seri film animasi berikutnya. Sungguh prestasi yang luarbiasa, bahwa industri film animasi mampu unggul dan berjaya dalam menyaingi film live action Hollywood yang telah lama membudaya, sangat dalam mengakar bahkan kuat mencengkeram industri film dunia. Fenomena filmfilm produksi Pixar, seperti E-wall, Cars, Finding Nemo, The Incredible, Monster Inc., Toy Story, dsb. merupakan bukti kedahsyatan seni komunikasi dan industri film animasi 3D. Film animasi kartun Walt Disney, Warner Bross, Nickeleodeon (Spongebob Squarepaints), Avatar maupun Naruto, Transformer menjadi bukti fenomenal. Animasi disukai bahkan digilai oleh berbagai kalangan, termasuk generasi muda dan bukan lagi fenomena tontonan anak kecil.

Bukan hanya dalam film, animasi juga tidak lepas dalam dunia permainan (games) digital dalam kurun waktu yang lama. Pergerakan-pergerakan visual yang disajikan dengan cara interaksi pun mempunyai peranan penting agar dapat menarik perhatian pemainnya. Bahkan di era digital dengan kecanggihan teknologi gadget, animasi games online menjadi sangat digemari banyak orang bahkan kalangan dewasa, remaja dan anak-anak sekalipun. Animasi selalu ada dalam era digital ini yang menyajikan gambar-gambar bergerak, baik dalam dunia cyber atau internet, televisi, sampai gadget dan smartphone sekalipun yang terus menyajikan perubahan dan pergerakan gambar.

Dalam tayangan televisi, juga demikian. Tayangan animasi menjadi tontonan menarik di industri pertelevisian global maupun nasional. Dari era tayangan animasi Donal bebek (Walt Disney), SpongeBob Squarepaints, sampai Naruto menjadi tayangan televisi yang mengglobal dan banyak disukai. Animasi Upin dan Ipin dan Adit, Sopo Jarwo dan G Town, Tayo, Saun the Sheep, Dora the Explorer, Dora Emon, Larva, Tayo, Naruto, si Juki adalah beberapa contoh animasi yang ditayangkan media televisi yang banyak digemari di televisi nasional Indonesia.

Persebaran kemampuan teknologis dan konten pembuatan karya animasipun sudah mulai menyebar ke berbagai negara. Artinya, perkembangan produsen karya animasi bukan lagi monopoli industri film Hollywood Amerika saja dengan berbagai studio besarnya, namun sudah menyebar ke berbagai belahan dunia. Banyak studio animasi bermunculan, tidak hanya di negara-negara maju dan kaya saja, tetapi sampai pula di negara-negara berkembang sekalipun. Banyak Sumber Daya Manusia dalam bidang animasi yang bermunculan di seluruh penjuru dunia, tidak terkecuali di Indonesia. Di Indonesia, studio-studio animasi juga banyak bermunculan, tidak hanya di Jakarta, tetapi juga di daerah-daerah yang potensial seperti Bandung, Jogja, Bali dll. Industri dalam bidang ini juga mulai tumbuh seiring dengan tumbuh berkembangnya ekonomi dan industri kreatif di Indonesia.

\section{METODE PENELITIAN}

Penelitian ini berusaha menjabarkan sinergi penggunaan dan pemanfaatan animasi dalam fluksusnya dengan bidang komunikasi di era media baru digital di Indonesia dengan menggunakan metode studi deskriptif dengan pendekatan kualitatif. Sugiyono (2017: 15) menjelaskan bahwa studi deskriptif memiliki tujuan untuk menggambarkan realitas yang sedang terjadi (Kriyantono, 2007:69) yang berhubungan dengan masalah yang diteliti. Metode kualitatif digunakan untuk mendapatkan data yang mendalam (Sugiyono, 2017:17). Hasil wawancara yang mendalam sebagai data yang dianalisis oleh peneliti dilakukan kepada para pemilik dan creator animasi (Animator) di studio atau perusahaan animasi di Indonesia. 
Perusahaan animasi yang memiliki project-project dalam pembuatan animasi untuk media komunikasi yang ada di Indonesia, dalam rentan kurun waktu 2017-2018. Dengan menganalisis data empiris, peneliti berusaha menggambarkan bagaimana keterkaitan ataupun hibridisasi antara industri animasi di Indonesia dengan perkembangan media komunikasi di era media baru digital.

\section{HASIL DAN ANALISIS}

\section{A. Memahami Animasi}

Kata animasi berasal dari bahasa Latin, anima yang berarti "hidup" atau animare yang berarti "meniupkan hidup ke dalam". Kemudian istilah tersebut dialih bahasakan ke dalam bahasa Inggris menjadi Animate yang berarti memberi hidup (to give life to), atau Animation yang berarti ilusi dari gerakan, atau hidup. Lazimnya istilah animation diartikan membuat film kartun (the making of cartoons). Istilah animation tersebut dialih bahasakan ke dalam bahasa Indonesia menjadi Animasi. Dalam Kamus Besar Bahasa Indonesia (2002:253) kata animasi diartikan lebih teknis lagi yaitu acara televisi yang berbentuk rangkaian lukisan atau gambar yang digerakkan secara mekanik elektronis sehingga tampak di layar menjadi bergerak. Ilusi dari gerakan tersebut dapat terjadi dengan cara menggerakkan secara cepat serangkaian gambar yang mempunyai gerakan secara bertahap dari masing-masing bagian objek gambar tersebut. Apabila rangkaian gambar tersebut digerakkan secara cepat, maka mata akan menangkap gerakan dari objek, dan bukan lagi gambar per frame-nya. Standar animasi seperti itu sering kali disebut sebagai stop-frame cinematography.

Kata "Animasi" itu sendiri sebenarnya penyesuaian dari kata "animation” (dalam bahasa inggris), berasal dari kata dasar "to animate", dalam kamus umum Inggris-Indonesia berarti "menghidupkan” (Wojowasito, 1997). Secara umum animasi merupakan suatu kegiatan menghidupkan, menggerakkan benda mati; Suatu benda mati diberikan dorongan kekuatan, semangat dan emosi untuk menjadi hidup dan bergerak, atau hanya berkesan hidup.

Arti animasi sendiri kemudian bisa diterjemahkan dalam berbagai pengertian, tidak hanya masalah dan berbentuk "film" saja, tetapi juga berbagai bidang kesenian dan media komunikasi yang lainnya. Animasi sering diartikan sebagai "menghidupkan" dari sesuatu benda mati atau benda statis yang kemudian bisa menciptakan gerak, atau kesan bergerak. Pengertian tersebut diartikan saat sebuah benda mempunyai gerakan atau kesan bergerak itu sendiri sehingga secara analitis memiliki jangkauan tempat, waktu dan juga material yang tidak terbatas.

Kata animasi berasal dari kata 'animae' atau 'to bring life'. Sebuah gambar atau ide yang di animasikan (secara sederhana ataupun kompleks) dapat menjadi sebuah karakter yang seolah-olah 'hidup' (Christian Tirtha, Handout: Life Skill Animation). Secara umum animasi merupakan suatu kegiatan menghidupkan atau menggerakkan benda mati: suatu benda mati diberikan dorongan kekuatan, semangat dan emosi untuk menjadi hidup dan bergerak atau hanya berkesan hidup (Djalle, 2006:02). Dari segi teknisnya, menurut Stan Hayward (1984:8), definisi animasi melingkupi berbagai macam bentuk format gambar yang direkam perframe, baik pada media film, video ataupun media digital lainnya. Banyak visi dan pengetahuan animasi diterapkan di masyarakat sebagai aplikasi yang berguna untuk suatu tujuan tertentu. Teknologi mekanik dipadukan dengan visi dan pengetahuan animasi bisa menghasilkan sesuatu yang bermanfaat, sering dinamakan animatronik (animasi secara elektronik). Animatronik ini bisa berwujud prototype manusia, binatang, dan boneka mekanik yang dianimasikan dengan suatu alat, sehingga memiliki kesan dan memang bisa bergerak seolaholah hidup, kesannya seperti memilik nyawa, walau memiliki keterbatasan tertentu karena memang sulit sekali animasi mekanik ini dibandingkan manusia atau binatang mekanik yang memiliki gerakan terpola dan terprediksi. Namun diakui bahwa benda mati bisa dihidupkan atau terkesan hidup dengan teknik animasi (Prakoso,2010:23-25).

Gambar yang diproyeksikan ke layar sebetulnya tidak bergerak, yang terlihat adalah gerakan semu, terjadi pada indera kita akibat perubahan kecil dari satu gambar ke gambar lain, adanya suatu "persistence of vision". Sehingga menghasilkan suatu ilusi gerak dari pandangan kita. Menurut penemuan Peter Mark Roget (dalam Prakoso, 2010: 26) bahwa mata dan otak manusia dapat menyimpan memori, dari sebuah image yang bergerak dalam waktu 1/50 detik setelah kejadian di depannya terekam olehnya. Tulisannya tentang The Persistance of Vision with regard to moving Object (1824) adalah sebagai lonjakan pemikiran di bidang psikologi ilmiah. The Persistence of vision mampu menafsir dan merangkai gerak untuk merekam kehidupan atau menciptakan kehidupan. Dengan penemuannya itu dapat menyingkap misteri mengapa gambar satu dengan gambar berikutnya seolah-olah sambung menyambung dan membuat gambar menjadi bergerak atau menciptakan image bergerak.

Bentuk perubahan ini secara psikologis menciptakan gerak, yang berarti ada sesuatu kekuatan yang tersimpan di dalamnya. Dasar pemikiran yang sederhana dari unsur-unsur di atas, dari sebuah benda yang berbentuk "sesuatu", berubah bentuk, bergerak dan menciptakan kehidupan itu menjadi dasar dalam studi bidang animasi. Animasi secara luas berbicara masalah bentuk suatu benda yang berubah-ubah menciptakan gerak dan kehidupan. Oleh karena itu satu kata animasi menjadi suatu pengertian, yang berarti menciptakan suatu yang bisa hidup atau bergerak. Dalam kamus InggrisIndonesia karya John M. Echols dan Hasan Sadily, Animate berarti yang hidup, bernyawa: (1) menghidupkan, menjiwai, menggelorakan, menyemarakkan. Animated: (1) yang mengasikkan, (2) hidup. Animation (kata benda): Semangat, semarak, kegembiraan. 
Animasi merupakan suatu karya yang kuat nuansa entertaint nya dan cukup mengasikkkan, namun dalam proses pembuatannya merupakan karya yang cukup rumit dan melibatkan kemampuan dari berbagai keahlian serta merupakan bidang khusus tersendiri dari motion picture. Sebagai bagian dari motion picture, gambar yang memiliki gerakan adalah essensi utamanya. Motion picture itu sendiri pada garis besarnya dapat dibedakan ke dalam dua macam jenis, yaitu: 1 . Live-action film dan 2. Animasi. Gerakan adalah nafas motion picture baik dari live action film maupun dari film animasi, namun ada beberapa perbedaan antara cinematic effect dari masing-masing bentuk karena live action merupakan hasil rekaman dari benda-benda hidup/kehidupan, sedangkan animasi adalah menghidupkan barang atau obyek mati sehingga menyerupai suatu kehidupan (Parsuki, 1996:1-2).

Boleh dikata, pengertian animasi bisa bermacam-macam dan seringkali saling berlainan sebagaimana se-begitu banyak pembuat film animasi atau para seniman yang menggeluti bidang animasi, baik yang berhubungan dengan kamera dengan menggunakan teknik frame per frame menjadi karakteristik atau yang menggunakan computer dan system digitalisasi atau Computer Generated Imagery (CGI), dalam dunia penciptaan film animasi. Dari sini boleh dikatakan sangat berguna untuk mengartikan film animasi yang mempergunakan teknik ini, single frame release. Tetapi masih banyak pendekatan dalam pembuatan film animasi yang tidak menggunakan teknik ini, demikian pula yang mempergunakan kamera video, atau tanpa mempergunakan kamera sama sekali, baik yang dikerjakan secara manual, digambar langsung diatas selluloid atau yang mempergunakan komputer atau peralatan lainnya (Prakoso, 2010:39-40).

Dengan mengetahui pengertian dan definisi animasi kita bisa melihat ruang lingkup dan batasan serta pemahaman dari istilah animasi. Dengan demikian, kita bisa memperoleh gambaran mengenai karakteristik, potensi dan kekuatan media serta gambaran teknis dalam lingkup pembuatan animasi, meskipun definisinya mulai banyak berkembang seiring dengan kemajuan teknologi informasi.

\section{B. Karakteristik Animasi Sebagai Media Komunikasi}

Komunikasi manusia terdiri atas pertukaran simbol untuk memahami konteks-konteks sosial dengan cara penyampaian pesan yang bisa saja secara auditif, seperti bahasa, sinyal suara, atau sinyal visual seperti gambar, gerak, atau auditif dan visual secara bersamaan.

Cara penyampaian pesan visual menjadi sangat penting pada saat ini sebagaimana pesan yang diberikan sebagai komunikasi terhadap visual, khususnya dalam animasi yang bukan hanya berbicara tentang pergerakan saja, tetapi juga terhadap seluruh simbol-simbol, baik secara tekstual, suara, serta gambar-gambar yang diberikan.

Unsur audio dan visual merupakan essensi pendukung film animasi. Namun unsur visual lebih dominan dalam komunikasi audiovisual media animasi. Mata manusia dihubungkan langsung dengan otak dan ini adalah sarana utama bagi manusia normal untuk belajar dan berhubungan dengan lingkungannya. Persistance Of Vision, dimana otak memiliki kemampuan merekam 1/50 detik visual yang ditangkap oleh mata. Dengan kemampuan otak tersebut memungkinkan penglihatan kasatmata sambung menyambung tanpa henti sehingga kesan gerak visual muncul.

Penglihatan menyediakan komunikasi visual paling langsung dengan pikiran, dan image / citra yang terbentuk tidak memerlukan penafsiran untuk dapat dipahami. Bahkan proses belajar dapat berlangsung sekaligus dengan pemahaman. Sebagaimana diketahui dalam proses komunikasi, seseorang hanya dapat pesan (message) jika sudah ada referensinya sebelumnya sehingga message tersebut dapat ditafsirkan maknanya. Dengan komunikasi visual, seseorang dapat mengisi referensinya sekaligus pada saat terjadi proses pemahaman makna message yang dihadapinya.

Suara (audio) merupakan unsur sekunder dalam komunikasi film animasi, sebab isinya mencapai otak melalui telinga dengan simbol yang harus ditafsirkan lebih dulu maknanya. Jika seorang tidak punya referensi atas suatu bunyi tertentu, ia tidak akan dapat menafsirkan maknanya.

Implikasi dari pengutamaan unsur visual ini dalam film animasi dicerminkan dari isi film yang 90 persen menggunakan unsur ini. Sementara hanya 10 persen dipakai untuk narasi atau dialog untuk memperjelas, atau berhubungan dengan gambaran yang sudah berlalu. Karenanya unsur bunyi (audio) hanya memainkan peranan membantu. Isi film yang terlalu banyak menggunakan unsur bunyi dengan sendirinya kurang memanfaatkan sifat medium visual.

Jika film animasi dapat memanfaatkan kekuatan visual ini, ia dapat digunakan dalam setiap masyarakat universal, terlepas dari latar belakang pendidikan maupun kebangsaannya. Medium visual menyampaikan ide dengan cara denotatif, yaitu langsung memperlihatkan benda kongkritnya. Berbeda dengan radio atau surat kabar yang menggunakan kata, yang untuk memahaminya harus melalui proses interpretasi. Message disini hanya dapat diinterpretasikan sesuai dengan maksud komunikator (penyampai pesan) jika komunikan (penerima pesan) juga memiliki referensi yang sama dengan komunikator dalam menghadapi message yang dihadapinya.

Meskipun dalam menghadapi medium visual penonton dapat mengalami proses belajar pada saat menginterpretasikan suatu message namun medium ini akan lebih efektif jika aspek visual yang ditampilkan memiliki konteks dengan diri penonton sebagai manusia. Dengan kata lain, message yang disampaikan menimbulkan kesan bagi penonton akan kemungkinan terkait dengan dirinya. Implikasinya dapat dilihat secara sederhana, bahwa orang akan lebih cenderung untuk mengidentifikasi obyek yang berupa manusia daripada ide. Misalnya, film yang menggunakan 
kehidupan manusia miskin akan lebih gampang diterima daripada gambaran statistik tentang kemiskinan.

Medium visual memiliki pengaruh besar sebab dalam menghadapi komunikasi visual, orang cenderung untuk mempercayai apa yang terlihat (pseudo event). Tetapi perlu diperhatikan, hal-hal yang terlihat punya tingkatan hal yang eksplisit (fakta) akan lebih mudah diterima dibanding dengan hal yang implicit (ide). Hal yang implicit biasanya bersifat konotatif, karenanya memerlukan penafsiran. Juga ini gampang ditolak jika berbeda dengan kerangka berfikir penonton, atau mengalami distorsi jika penonton sudah punya pendapat sebelumnya. Akibat kekuatan mempengaruhi inilah masyarakat menganggap perlu adanya sensor terhadap media audiovisual termasuk film animasi, berbeda dengan medium komunikasi lainnya (Siregar, 1985:21-22).

Gerak (motion) dan pergerakan (movement) adalah kata kunci dalam animasi, tidak terkecuali seperti yang diinginkan dalam sebuah film yang menggambarkan seperti pertujukan dengan slide (still photo) atau buku komik yang seharusnya bisa digerakkan. John Hallas menulisnya seperti ini, “Animasi adalah desain yang bergerak, yang merupakan subyek yang melintas dengan memerlukan waktu. Sebuah desain, dalam animasi akan kehilangan identitas sebagaimana kalau bentuk bayangan statis dalam ruang dan waktu tertentunya. Ruang dan waktu adalah material kasar yang sangat penting untuk diolah oleh seorang animator".

Hasil penelitian ini, menjelaskan faktor penting mengapa media komunikasi menggunakan pendekatan visual animasi:

1. Dramatis. Animasi mampu melebih-lebihkan adegan atau action tertentu dalam media komunikasi karenanya ciri komunikasi yang hiperbolik terwakili dalam ciri animasi yang eksaggeration. Intinya animasi mahir dalam urusan melebih-lebihkan. Dengan eksaggeration ini mampu memberikan Efek takjub yang bisa menyihir perhatian. Dramatisasi dalam animasi di media komunikasi ini biasanya didukung pula oleh factor dramatis seperti efek kejutan (surprise), terutama kejutan visual.

2. Mendukung visualisasi yang sulit dilakukan dengan live shoot. Animasi mampu memperkuat bahkan bisa menciptakan adegan yang tidak bisa diterjemahkan atau sulit dilakukan dalam penyutradaraan ataupun shooting atau rekaman secara langsung, seperti mengarahkan acting bayi, atau hewan-hewan, atau makhluk angkasa luar, atau kuman-kuman jahat dsb. Animasi juga mampu memperjelas ilustrasi dari penggambaran visual yang sulit, atau berbahaya, atau tokoh fiktif, atau berupa simulasi atau visualisasi imajinasi.

3. Animasi mampu mendekati segmen anak-anak secara lebih dekat dengan menarik perhatian dengan tokohtokoh kartun, apalagi yang sudah akrab. Bagi segmen tertentu, terutama anak-anak dengan daya khayal dan imajinasi yang masih melekat kuat dan sangat dominan, kehadiran animasi sangat mengena di hati dan otak mereka. Animasi mampu menghadirkan visualisasi dunia animasi yang diakrabi dalam dunia imajinasi anakanak.

4. Efisiensi biaya. Produksi Animasi tidak banyak melibatkan crew dan talent atau bintang iklan atau tokoh terkenal yang biasanya menyedot dana yang cukup besar. Dengan tokoh, tempat, property atau alat yang serba rekaan computer digital atau gambar, biaya bisa lebih diminimalisir. Cukup dengan Komputer yang canggih dengan animator yang handal, animasi iklan sudah bisa diciptakan.

5. Animasi bisa membuat lebih kuat dan cepat dalam memperkuat pesan visual iklan yang berdurasi singkat. Dengan kelebihan teknik animasi yang berkembang pesat, imajinasi sekalipun dapat divisualkan dengan jelas dan nyata. Bahkan kedigdayaan animasi, mampu melebihi mimpi-mimpi.

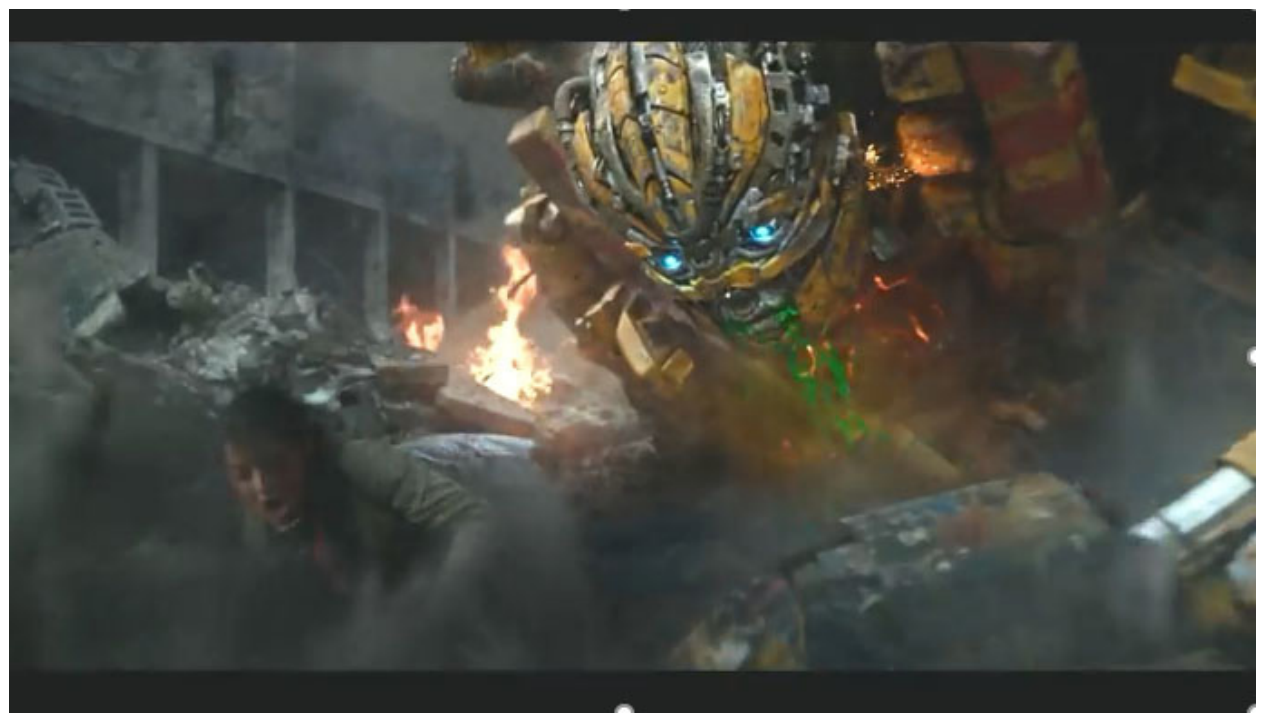

Gambar 1. Cuplikan film Transformers 
6. Selain tampilan yang menarik dan dramatis, animasi ini juga bisa menjadi visual tambahan dalam perfilman yang mungkin tidak dapat dibuat oleh manusia secara nyata, atau jika bisa dibuat maka mungkin butuh dana yang cukup besar untuk membuatnya. Peranan komputer grafis menjadi kebutuhan yang cukup penting untuk membuat ide dan konsep di luar batas kemampuan manusia dan menjadikannya "seakan-akan" nyata. Disinilah peranan animasi menjadi penting untuk menciptakan hal tersebut.

7. Aspek pada animasi mempunyai definisi sederhana, tetapi penerapannya yang cukup luas, karena berbicara pergerakan yang realistis dan unrealis, serta waktu seperti kecepatan atau perlambatan. Benturan, pantulan, dan semuanya seperti kejadian nyatanya. Dengan begitu, animasi diharapkan dapat menyuguhkan informasi dan mengkomunikasikan kepada khalayak agar dapat memahami apa yang ingin disampaikan. Bisa jadi sang animator ingin memberikan informasi tentang suatu kejadian, suasana, kemampuan, atau emosi terhadap subjek yang ada, seakan-akan visual yang ditampilkan sedang berkata-kata selayaknya orang berbicara sehingga cukup dengan animasi tersebut, informasi yang disampaikan bisa dipahami oleh para penontonnya.

8. Kelebihan animasi lainnya adalah dapat digunakan untuk mengilustrasikan atau menggambarkan ide-ide dan konsep yang sulit serta tidak bisa dijangkau atau dibuat dengan shooting biasa (live action). Dalam hal ini animasi dapat mewujudkan suatu gambaran atau visualisasi yang sulit dan membuat efek-efek khusus yang tidak bisa dibuat dengan media konvensional, jika dibuat akan memakan biaya yang banyak dan waktu yang lama (lebih efisien). Artinya animasi mampu menjadi media komunikasi audio visual yang spektakuler dan dahsyat dalam membuat simbol-simbol visual dan auditif dalam pesan-pesan yang disampaikannya.

9. Dalam animasi sebetulnya yang terjadi adalah suatu gerak, hidup, dunia baru yang tidak ada, atau tidak pernah terjadi. Karena itu akan terjadi suatu "kehidupan" yang tidak seperti yang kita kenal sehari-hari. Suatu dunia buatan (arrifisial \} yang diciptakan manusia. Jagad (dunia) buatan ini mempunyai tokoh (karakter), alam, atmosfer, tempo, irama, suasana, dan logika yang berbeda dengan dunia kenyataan (realita). Dunia baru inilah yang harus diciptakan oleh animator dengan konsep dan keterampilan yang cukup memadai. Dunia buatan ini, tidak boleh sebagai tiruan dari dunia nyata, walaupun bisa mengambil sumber dari realita kehidupan. Segala sesuatu yang terjadi di dalam dunia buatan tersebut, harus dapat dirasakan sebagai suatu kejadian dari jagad lain yang utuh. Hal itu yang akan membuat film animasi menarik untuk ditonton dan memiliki kelebihan dari film yang merupakan representasi dunia nyata.

\section{Aplikasi Fluxus Animasi dan Komunikasi di Era Media Baru Digital}

Di dasawarsa tahun 1960an, muncul kembali gerakan internasional fluxus. Gerakan interdisiplin ini bisa disebut kolaborasi berbagai disiplin seni: seni visual, animasi, teater, tari, dan musik. Disiplin seni atau media itu tampil dalam semangat kesetaraan. Gerakan ini kemudian hari melahirkan genre seni performance, genre hibrida pertujukan yang lebih condong menginduk pada kelembagaan seni visual. Fluxus yang Avant garde itu mengkaji ulang seni modernis yang mengukuhkan spesialisasi dan dominasi institusi museum.

Terkait fluxus ini, Pakar media baru Michael Rush menegaskan bahwa:

Fluxus.. opened the event to multiple interpretations as well as accidents. Anything could happen during one of these events.. [..] the viewer not only completes, but actually becomemes the work in his or her direct participation in the event. (New Media in Late 20 th -Century Art, Thames and Hudson, London, 1999: 113).

Fluxus menekankan pentingnya peristiwa (event), sebuah kejadian "kecelakaan" berdimensi waktu. Dan yang paling radikal ialah mentasbihkan penonton sebagai karya, sebagai pengejawantahan partisipasi. Performance pada kenyataannya merupakan hibridisasi dari seni visual yang secara substansial semangat melibatkan public serta menumpukkan wacana realitas artistik dengan kehidupan realistik menjadi komitmen.

Dalam fluxus, interaktivitas mendorong konsep penonton menjadi aktor atau dalam istilah lain sebagai interaktor, pihak yang aktif. Dalam perkembangan animasi dan komunikasi, penonton atau pengguna gadget atau teknologi atau media mendapatkan peran sentral, bukan sekedar obyek lagi.

Dengan kemajuan digitalisasi media, manusia semakin mudah mengintervensi waktu dan ruang. Dengan media digital, realitas actual kemudian sulit dibedakan dengan realitas virtual. Interaktivitas yang menjadi ciri teknologi digital membaurkan antara definisi menonton dan berpartisipasi. Kondisi media seperti ini mendorong dua aspek. Di satu sisi menyokong interaksi dari berbagai disiplin semisal animasi, fotografi, sinema, video dan performance; disaat yang sama mengawinkannya. Maka terjadilah hibridisasi kedua yang menawarkan pengalaman seni maupun pengalaman bermedia yang berbeda dari asal muasalnya (Murti, 2009:227).

Secara historis, perkembangan media baru mempunyai kaitan dengan Fluxus, juga seni konseptual, tetapi sebenarnya keberadaan media baru lebih dipengaruhi maraknya teknologi media. Media baru itu sendiri menurut Pakar Media Baru Lev Manovich dan Lister, didefinisikan sebagai cara baru dalam memproduksi, mengapresiasi, menyimpan dan mendistribusikan gagasan dengan teknologi media (Murti, 2009:228). 
Animasi yang telah berfluxus dengan dunia komunikasi, bisa fleksibel diterapkan dalam berbagai bentuk media baru, yang berkembang sesuai dengan kebutuhan masyarakat. Sebagai sebuah Oase yang menarik, animasi akan didatangi oleh para musafir atau pengembara dari disiplin-disiplin ilmu yang lain. Pertemuan dan interaksi antara Musafir dengan oase tersebut mampu melahirkan sinergi karya-karya baru yang menarik dan kreatif. Pada akhirnya, interaksi tersebut menempatkan animasi dalam wilayah-wilayah interdisipliner, animasi ada dimana-mana dalam bentuk, kegunaan dan penerapan yang berbeda-beda.

Berdasarkan hasil penelitian, Aplikasi animasi yang berkembang dewasa ini (di era media baru yang serba digital), animasi merupakan hibridisasi atau fluksus dari percampuran berbagai bidang atau ilmu atau disiplin. Lebih lanjut, penelittian menunjukkan bahwa Animasi dalam fluksusnya dengan dunia komunikasi banyak digunakan antara lain untuk memproduksi content: TV Graphics, Scientific Visualization, Flight Simulation, Military, Space, Architecture, Archeology, Medical, Film, Special Effect, Advertising, Corporate video, Education, Games, Art, Multimedia, dan lain-lain.

Animasi adalah sebuah bahasa visual yang sudah universal. Ia merupakan bentuk komunikasi non-verbal, sebagai kesatuan juga bisa saja menjadi elemen visual. Karena kekhususan dan keunikannya, teknik animasi telah berkembang pesat dan dipakai secara luas di berbagai bidang, tidak hanya di film, tetapi juga di bidang periklanan, televisi, maupun presentasi ilmiah dalam format virtual. Animasi selalu mendukung kemajuan dunia Komunikasi sebagai konsekuensi inovasi hasil fluxus, atau hibridisasi dan penggabungan dengan segala disiplin ilmu dan seni serta berbagai disiplin atau bidang yang terus berkembang.

\section{KESIMPULAN}

Animasi telah berkembang sedemikian rupa dan begitu pesat merambah berbagai aspek penting kehidupan manusia. Hal ini bisa mengantarkan animasi sebagai bagian penting dalam kehidupan manusia modern dalam peradaban yang semakin maju. Disadari atau tidak, animasi telah menjadi kebudayaan audiovisual baru masyarakat modern. Animasi telah berproses dan berkolaborasi dengan disiplin ilmu lain atau wilayah terapan lain, sehingga melahirkan banyak variannya dan semakin mengukuhkan keberadaan animasi di berbagi tempat, interdisipliner dan multi terapan. Suatu keadaan dimana animasi semakin eksis dan fleksibel serta sangat dibutuhkan. Animasi bisa kemana-mana, kapan saja, bahkan ada dimana-mana, termasuk di mata, otak bahkan hati siapa saja.

Animasi telah bermutasi menjelma sebagai agen penerjemah imajinasi dan realitas yang fantastis dan dramatis. Apa yang tidak bisa dilakukan oleh gambar motion picture (gambar atau citra bergerak audiovisual pada umumnya) yang sifatnya live action, animasi mampu memberikan solusi dramatis. Motion picture dalam animasi mampu membuat visualisasi yang sepertinya tidak mungkin dilakukan atau tidak mungkin ada menjadi sangat mungkin dan terlihat seolah nyata ada. Animasi juga memberikan ruang bagi gerak-gerak makhluk hidup yang unik, dilebih-lebihkan (exaggeration) bahkan yang jarang terjadi dalam tangkapan visual kehidupan nyata. Bahkan benda yang dianggap tak hidup, dapat terkesan hidup, seolah-olah memiliki nyawa dan menemukan kehidupannya berkat kemampuan animasi.

Animasi telah mampu menjadi media untuk estetika seni, dengan kemampuan visualisasinya yang spektakuler serta ceritanya yang fantastis dengan imajinasi yang tak terbatas. Animasi mampu mengantarkan dirinya menjadi bagian dari seni kontemporer dunia. Disamping itu, animasi juga telah menjelma menjadi ladang bisnis yang menjanjikan, dimana animasi menjadi bagian dari sistem perekonomian dengan kekuatan industri kreatif yang menjanjikan.

Media Baru, Gadget dan Televisi di Indonesia sudah menyadari potensi besar penggunaan animasi sebagai pendekatan visual yang efektif, yang mampu mencuri perhatian khalayak luas. Animasi telah diterima sebagai bagian dari strategi dan budaya komunikasi media masa di era digital di Indonesia. Kecanggihan animasi dan Teknologi informasi komunikasi telah melahirkan titik temu fluksus yang sinergis antara keduanya.

Dalam Fluksus animasi dan media komunikasi di era Media Baru digital, ekspresi dan eksplorasi seni serta kreativitas memungkinkan tertampung di dalamnya, melebihi konvensi-konvensi umum yang lazim dikenal. Dalam kreatifitas penciptaan karya animasi dengan media komunikasi, dewasa ini telah mengalami dinamika yang luar biasa dan maju pesat dalam berbagai ekspresi bentuk, media, isi maupun cara penyajiannya bahkan cara menikmatinya. Kreativitas tumbuh secara progresif dan berubah mengikuti perkembangan dan kemajuan zaman. Kemunculan komunikasi dalam wilayah teknologi animasi ini sangat sinergis dengan kehidupan. Kompromi-kompromi dan persilangan-persilangan antara keduanya justru melahirkan suatu wilayah baru yang menarik.

\section{DAFTAR PUSTAKA}

Chatia Hastari et.al, (2011), New Media (Teori dan Aplikasi), Jawa Tengah Solo : Ikom Pascasarjana UNS

Djalle, Zaharuddin S., (2007), 3D Animation Movie using 3D STUDIO MAX, Bandung: Penerbit Informatika

Engler, Robi, 2008. Animation Workshop, Cepte TV, Singapura

Gumelar, M.S,(2004) Memproduksi Animasi TV, Jakarta : Grasindo 
Kriyantono, Rachmat, 2007, Riset Komunikasi, Jakarta : Kencana

Kusrianto, Adi, (2007), Pengantar Desain Komunikasi Visual (Graphic, Advertising, Multimedia), Yogyakarta: Penerbit Andi

Mascelli Yoseph (terjemahan Biran, Misbach Yusa), (1986), 5 C (Camera Angle, Compotition, Continity, cutting, Close Up) in Cinematogrhapy), Jakarta: Yayasan Citra

Madsen, Roy, (1969), Animated Film (Concepts, Methods, Used). Interland Publishing Inc. New York.

Mc Cloud, Scott, 2001) Understanding Comics (Memahami Komik), Jakarta: KPG (Kepustakaan Populer Gramedia)

Murti, Krisna, (2009) Essay tentang seni Video dan Media Baru, IVAA, Yogyakarta

Parsuki (2010), Dasar Dasar Animasi, Yogyakarta : Penerbit FSMR ISI Yogyakarta

Prakoso, Gatot, (2010) Animasi (Pengetahuan Dasar Film Animasi Indonesia). Jakarta: Yayasan Seni Visual Indonesia IKJ.

Ranang, Basendar, Asmoro, (2010), Animasi Kartun, Dari Analog sampai Digital, Jakarta : PT Indeks

Roberts, Steve, (2006) Animasi Karakter 3D, Jatim: Bayu Media

Ruslan, Arief, (2016) Animasi (Perkembangan dan Konsepnya), Bogor: Penerbit Ghalia Indonesia

Sugiyono (2017), Metode Penelitian Kuantitatif, kualitatif, dan R\&D, Bandung : Alvabeta.

Thomas, Frank \& Johnson Ollie. (1981). Disney Animation (The Illusion of Life), Abbeville press, Publisher, New York. Soewignya, (2005), Animasi Flash, Yogyakarta : Atmajaya Press.

Suyanto, Aryanto Y, (2006), Merancang Film Kartun Kelas Dunia, Yogyakarta : Penerbit Andi

Whitaker, Halas (2006), Timing For Animation (Pengaturan Waktu untuk Film Animasi), Jatim : Bayu Media. 
